Jurnal KBP

Volume 1 - No. 2, September 2013

\title{
ANALISIS PERHITUNGAN DAN PELAPORAN PPH PASAL 25 PADA PT SELAGO MAKMUR PLANTATION
}

\author{
Dewi Zulvia \\ STIE "KBP" Padang \\ (dewizulvia@gmail.com)
}

\begin{abstract}
The research was conducted at PT SELAGO MAKMUR PLANTATION Padang. This study aims to conduct an analysis of 25 calculation and reporting of PPH Article 25 on the PT SELAGO MAKMUR PLANTATION Padang and to find out if the company does with the tax obligations applicable laws. In this study the author uses primary and secondary data, while data collection techniques by conducting field research and library research. Analysis method used consists of qualitative and quantitative analysis.

From the research, commercial accounting profit according to the PT SELAGO MAKMUR PLANTATION the profits in fiscal 2006 amounting to Rp. 19,943,110,563 and Rp. 48,840,381,127.03. Calculation of PPH Article 25 that the company paid in 2006 was Rp. Rp. 637783403 and in 2007. PT SELAGO MAKMUR PLANTATION in SSP payments made in an independent bank which conducted research on the tax return no later than two months after the tax return is received.

From penelitian, the authors suggest to PT SELAGO MAKMUR PLANTATION to continue to tax obligations under applicable law.
\end{abstract}

Keywords: calculation and reporting of Income Tax Article 25.

\section{PENDAHULUAN}

Saat ini, pajak merupakan kontributor terbesar dari APBN kita yang berarti perannya sangat besar bagi kelangsungan pembangunan. Untuk meningkatkan penerimaan pajak, diperlukan perangkat yang mengatur "pemajakan" terhadap rakyat. Jenis pajak yang dipungut oleh pemerintah adalah pajak penghasilan. Pajak penghasilan adalah pajak yang dikenakan atas penghasilan yang diperoleh atau diterima oleh Wajib Pajak selama satu tahun pajak. Pajak penghasilan diatur dalam UndangUndang Nomor 7 Tahun 1983 telah beberapa kali diubah terakhir dengan Undang- Undang Nomor 17 Tahun 2000 tentang perubahan ketiga atas Undang-Undang Nomor 7 Tahun 1983 tentang Pajak Penghasilan dan perubahan yang keempat UndangUndang Nomor 36 Tahun 2008. Kewajiban untuk membayar pajak penghasilan berada pada Wajib Pajak. Wajib Pajak adalah pribadi atau badan yang menurut ketentuan peraturan perundang-undangan perpajakan ditentukan untuk melakukan kewajiban perpajakan, termasuk pemungut pajak atau pemungut pajak tertentu.

Pada akhir tahun, bagi Wajib Pajak diwajibkan untuk melakukan perhitungan pajak yang terutang atas seluruh penghasilan yang diterima/ diperoleh dalam satu tahun pajak. Pada dasarnya PPh yang terutang dihitung dari penghasilan keseluruhan yang diperoleh pada akhir tahun. Adapun besarnya angsuran $\mathrm{PPh}$ setiap bulan atas $\mathrm{PPh}$ yang terutang tersebut dikenal dengan PPh Pasal 25. Pajak penghasilan 
Pasal 25 merupakan salah satu pasal dalam Undang-Undang Nomor 10 Tahun 1994 yang dimaksud untuk meringankan beban warga negara dalam membayar pajak terutang. Cara yang diperkenankan adalah mengangsur hutang pajaknya dalam tahun pajak.

Angsuran $\mathrm{PPh}$ Pasal 25 dijadikan sebagai kredit pajak terhadap seluruh pajak yang terutang atas seluruh penghasilan Wajib Pajak pada akhir tahun pajak. Pelunasan PPh Pasal 25 dilakukan oleh Wajib Pajak pada masa bulanan dan akhir tahun. PPh Pasal 25 pada masa bulanan adalah angsuran PPh yang diperkirakan akan terutang dari Wajib Pajak pada akhir tahun. Wajib Pajak yang harus memperhitung kan, membayar, dan melaporkan PPh Pasal 25 masa bulanan adalah Wajib Pajak perseorangan maupun badan ternasuk BUT.

Wajib pajak yang wajib menyetor $\mathrm{PPh}$ Pasal 25 namun tidak menyetor $\mathrm{PPh}$ Pasal 25 atau kurang menyetor $\mathrm{PPh}$ Pasal 25, akan diterbitkan surat ketetapan pajak untuk menagih $\mathrm{PPh}$ Pasal 25 yang tidak atau kurang disetor ditambah dengan sanksi administrasi sesuai dengan ketentuan UndangUndang perpajakan. Untuk melaporkan pembayaran pajak PPh Pasal 25 harus membuat SPT. SPT adalah surat yang oleh Wajib Pajak digunakan untuk melaporkan perhitungan dan/ atau pembayaran pajak, objek pajak dan/ atau bukan objek pajak dan/ harta dan kewajiban, sesuai dengan ketentuan peraturan perundang-undangan perpajakan (Pasal 1 angka 11 UU KUP). Dalam rangka menguji kepatuhan dalam perpajakan maka diperlukan pemeriksaan pajak. Kewajiban perpajakan dan menguji pemenuhan kewajiban perpajakan dilakukan dengan menelusuri kebenaran SPT, pembukuan atau pencatatan, dan pemenuhan kewajiban perpajakan lainnya, dibandingkan dengan keadaan atau kegiatan usaha sebenarnya dari Wajib Pajak.

Pt Selago Makmur Plantation yang bergerak dibidang perkebunan kelapa sawit yang pelaksanaan PPh Pasal 25 yang dilakukan oleh perusahaan apakah sesuai dengan ketentuan perpajakan. Sebelum menghitung PPH Pasal 25 akan dilakukan terlebih dahulu koreksi fiskal dari laporan Laporan Laba Rugi perusahaan.

\section{TINJAUAN PUSTAKA DAN HIPOTESIS}

Pajak memiliki berbagai definisi, yang pada hakikatnya mempunyai pengertian sama. Beberapa pengertian pajak yang dikemukakan para ahli yang dikutip oleh Wirawan B. Ilyas dan Rudy Suhartono dalam bukunya Pajak Penghasilan (2009:1) adalah :

Pengertian pajak menurut Nigthtingale (2005: 5) sebagai berikut : “A cumpolsory contribution, imposed by Government, and while tax payers many receive nothing identifiable in return for their contribution, they nevertheless have the benefIt of living in a relative by educated, healthy and save society “

Pengertian pajak menurut Prof. Dr. Rochmat Soemitro (R. Santoso Brotodihardjo,1993 : 5-6) sebagai berikut :

" Pajak adalah peralihan kekayaan dari pihak rakyat kepada kas negara untuk membiayai pengeluaran rutin dan "surplusnya" digunakan untuk "public saving" yang merupakan sumber utama untuk membiayai "Public Investment" Pengertian pajak menurut S. I. Djajaningrat ( Munawir, 1995 : 3 ) sebagai berikut: "Pajak sebagai suatu kewajiban menyerahkan sebagian daripada kekayaan ke kas negara disebabkan suatu keadaan, kejadian dan perbuatan yang memberikan kedudukan tertentu, tetapi bukan sebagai hukuman, menurut peraturan yang ditetapkan 
pemerintah serta dapat dipaksakan, tetapi tidak ada jasa timbal balik dari negara secara langsung, untuk memelihara kesejahteraan umum."

Pengertian pajak menurut Prof. Dr. P.J.A. Adriani, dalam R. Santoso Brotodiharjo, SH (1991: 2) sebagai berikut :

" Pajak adalah iuran kepada negara (yang dapat dipaksakan) yang terutang oleh yang Wajib membayarnya menurut undang-undang yang tidak mendapatkan prestasi kembali, yang langsung dapat ditunjuk, dan yang gunanya adalah untuk membiayai pengeluaran-pengeluaran umum berhubung dengan tugas negara untuk menyelenggarakan pemerintahan"

Dari defenisi pajak yang dikemukakan oleh para ahli diatas dapat disimpulkan bahwa pajak adalah alat bagi pemerintah untuk mencapai tujuan agar didapatkannya penerimaan dari masyarakat untuk membiayai pengeluaran rutin negara, pembangunan sosial dan ekonomi bangsa. Pajak secara bebas dapat dikatakan sebagai suatu kewajiban warga berupa pengabdian untuk membiayai berbagai keperluan negara nantinya juga bertujuan untuk kesejahteraan dan kemakmuran bangsa dan negara. Pajak adalah salah satu instrumental fiskal pemerintah yang digunakan untuk membiayai pembangunan nasional. Pajak merupakan wujud kemandirian suatu bangsa atau negara dalam pembiayaan pembangunan yaitu menggali sumber dana yang berasal dari negeri. Pajak juga merupakan alat bagi pemerintah untuk mencapai tujuan agar didapatkannya penerimaan dari masyarakat untuk membiayai pengeluaran rutin negara, pembangunan sosial dan ekonomi bangsa. Pajak secara bebas dapat dikatakan sebagai suatu kewajiban warga berupa pengabdian untuk membiayai berbagai keperluan negara yang nantinya juga bertujuan untuk kesejahteraan dan kemakmuran bangsa dan negara.

Pajak juga mempunyai beberapa fungsi yang dikutip dari Prof. Dr. Mardiasmo, MBA.,

Ak dalam bukunya Perpajakan (2006:3), yaitu :

1. Fungsi budgeter

Pajak sebagai sumber dana bagi pemerintah untuk membiayai pengeluaran-pengeluarannya, yaitu pengeluaran rutin dan pembangunan.

2. Fungsi mengatur

Pajak sebagai alat untuk mengatur atau melaksanakan kebijakan pemerintah dalam bidang sosial, ekonomi, politik, budaya, pertahanan dan keamanan.

Tarif pajak merupakan angka atau persentase yng digunakan untuk menghitung jumlah pajak yang terutang. Tujuan dari pembentukan tarif pajak adalah untuk mencapai keadilan. Tarif pajak ada 4 yang dikutip dari Sunarto SE., MM dalam bukunya Perpajakan 1 (2003:4), yaitu :

1. Tarif Tetap

Tarif dengan jumlah atau angka tetap berapapun yang menjadi dasar pengenaan pajak.

2. Tarif Proporsional

Tarif dengan persentase tetap berapapun jumlah yang menjadi dasar pengenaan pajak, dan pajak yang harus dibayar selalu akan berubah sesuai dengan jumlah yang akan dikenakan.

3. Tarif Progresive

Tarif dengan persentase yang semakin naik (meningkat) apabila jumlah yang menjadi dasar pengenaan pajak meningkat (naik).

4. Tarif Degresif

Tarif dengan persentase yang semakin turun apabila jumlah yang menjadi dasar pengenaan pajak meningkat (naik). 
Menurut Prof. Dr. Mardiasmo, MBA., Ak dalam bukunya Perpajakan (2006:7) menyatakan bahwa sistem pemungutan pajak terbagi atas 3, yaitu :

1. Offcial Assessment Sistem

Adalah suatu system pemungutan yang member wewenang kepada pemerintah (fiskus) untuk menentukan besarnya pajak yang terutang oleh Wajib Pajak.

Ciri-cirinya:

a. Wewenang untuk menentukan besarnya pajak terutang pada fiskus.

b. Wajib Pajak bersifat pasif.

c. Utang pajak timbul setelah dikeluarkan surat ketetapan pajak oleh fiskus.

2. Self Assessment System

Adalah suatu system pemungutan pajak untuk menentukan sendiri besarnya pajak yang terutang.

Ciri-cirinya:

a. Wewenang untuk menentukan besarnya pajak terutang ada pada Wajib Pajak sendiri.

b. Wajib Pajak aktif, mulai dari menghitung, menyetor dan melaporkan sendiri Wajib Pajak yang terutang.

c. Fiskus tidak ikut campur dan hanya mengawasi.

3. With Holding System

Adalah suatu sistem pemungutan pajak yang memberi wewenang kepada pihak ketiga (bukan fiskus dan bukan wajib pajak yang bersangkutan) untuk menentukan besarnya pajak yang terutang oleh Wajib Pajak.

Ciri-cirinya: wewenang menentukan besarnya pajak yang terutang ada pada pihak ketiga, pihak selain fiskus dan Wajib Pajak.

Teori Pemungutan Pajak Dalam buku Perpajakan yang dikutip dari Prof. Dr. Mardiasmo, MBA., Ak (2006:10) ada beberapa teori yang mendukung pemungutan pajak antara lain :
1. Teori Asuransi

Negara melindungi keselamatan jiwa, harta benda, dan hak-hak rakyatnya. Oleh karena itu rakyat harus membayar pajak yang diibaratkan sebagai suatu premi asuransi karena memperoleh jaminan perlindungan tersebut.

2. Teori Kepentingan

Pembagian beban pajak kepada rakyat didasarkan pada kepentingan (misalnya perlindungan) masingmasing orang. Semakin besar kepentingan seseorang terhadap negara, makin tinggi pajak yang harus dibayar.

3. Teori Daya Pikul

Beban pajak untuk semua orang harus sama beratnya, artinya pajak harus dibayar sesuai daya pikul masing-masing orang. Untuk mengukur daya pikul dapat digunakan 2 pendekatan yaitu:

a. Unsur objektif, dengan melihat besarnya penghasilan atau kekayaan yang dimiliki seseorang.

b. Unsur subjektif, dengan memperhatikan besarnya kebutuhan materil yang harus dipenuhi

Dalam perpajakan ada terdapat unsurunur pajak yang terdapat dalam kutipan Sunarto SE., MM dalam bukunya Perpajakan 1 (2003:6), yaitu :

1. Iuran dari rakyat kepada negara. Yang berhak memungut pajak hanyalah negara. Iuran tersebut berupa uang (bukan barang).

2. Berdasarkan undang-undang.

Pajak dipungut berdasarkan atau dengan kekuatan undang-undang serta aturan pelaksanaannya.

3. Tanpa jasa timbal balik atau kontraprestasi dari negara yang secara langsung dapat ditunjuk. Dalam pembayaran pajak tidak dapat ditunjukkan adanya kontraprestasi individual oleh pemerintah. 
4. Digunakan untuk membiayai rumah tangga, yakni pengeluaranpengeluaran yang bermanfaat bagi masyarakat luas.

Pada umumnya tahun pajak sama dengan tahun takwim atau tahun kalender. Akan tetapi Wajib Pajak dapat menggunakan tahun pajak tidak sama dengan tahun takwim dengan syarat konsisten (taat asas) selama 12 bulan, dan melapor/memberitahu kepada Kantor Pelayanan Pajak (KPP) setempat. Cara menentukan suatu tahun pajak adalah sebagai berikut:

1. Tahun pajak sama dengan tahun takwim.

Pembukuan dimulai 1 Januari 2005 dan berakhir 31 Desember 2005, disebut tahun pajak 2005.

2. Tahun pajak tidak sama dengan tahun takwim.

a. Pembukuan dimulai 1 Juli 2005 dan berakhir 30 Juni 2006. Disebut tahun

pajak 2005 karena 6 bulan pertama jatuh pada tahun 2005 .

b. Pembukuan dimulai 1 April 2005 dan berakhir 31 Maret 2006. Disebut rahun pajak 2005 karena lebih dari 6 bulan jatuh pada tahun 2005.

c. Pembukuan dimulai 1 Oktober 2005 dan berakhir 30 September 2006. Disebut tahun pajak 2006 karena lebih dari 6 bulan jatuh pada tahun 2006.

Salah satu pajak yang ada khususnya di Indonesia adalah pajak penghasilan. Banyak para ahli dan menurut PSAK yang memberikan definisi atas pajak penghasilan. Antara lain pengertian pajak penghasilan menurut PSAK no. 46 paragraf 7 menyatakan : " Pajak yang dihitung berdasarkan peraturan perpajakan dan pajak kini dikenakan atas penghasilan kena pajak perusahaan"
Menurut Pasal 1 Undang-undang Nomor 7 Tahun 1983 sebagaimana terakhir telah diubah dengan Undangundang Nomor 36 Tahun 2008 tantang Pajak Penghasilan (UU PPh) yang dikutip dari Wirawan B. Ilyas dan Rudy Suhartono dalam bukunya Pajak Penghasilan (2009:11) ditegaskan bahwa Pajak Penghasilan dikenakan kepada subjek pajak (orang pribadi atau badan) atas penghasilan yang diterima atau diperolehnya selama 1 tahun pajak (tahun takwim/tahun buku)

Setelah diketahui Subjek Pajak dan Objek Pajak, maka langkah berikutnya adalah menghitung besarnya $\mathrm{PPh}$ yang terutang. Komponen untuk menghitung besarnya $\mathrm{PPh}$ yang terutang adalah tarif Pajak Penghasilan dikalikan dasar perhitungan pajak. Tarif Pajak Penghasilan menentukan besarnya jumlah PPh yang terutang yang berupa persentase tertentu yang sudah ditetapkan oleh UU PPh. Sedangkan dasar penghitungan pajak menurut UU $\mathrm{PPh}$ ada yang berdasarkan jumlah penghasilan bruto dan ada pula berdasarkan jumlah penghasilan neto yang tergantung jenis penghasilannya.

Jumlah penghasilan yang menjadi dasar penghitungan pajak tersebut adalah jumlah penghasilan yang diterima atau diperoleh dalam 1 tahun pajak. Menurut penjelasan Pasal 1 UU PPh dijelaskan bahwa yang dimaksud dengan tahun pajak adalah tahun takwim (1 Januari s.d. 31 Desember), namun dapat juga menggunakan tahun buku yang tidak sama dengan tahun takwim dengan syarat meliputi jangka waktu 12 bulan.

Yang mana subjek Pajak Penghasilan menurut Djoko Muljono dalam bukunya Pengantar PPh dan PPh 21 (2007:1) subjek pajak dapat dibedakan menjadi :

1. Subjek pajak dalam negeri

Adalah orang pribadi atau badan yang bertempat tinggal atau berkedudukan di dalam Indonesia 
yang dapat menerima atau memperoleh penghasilan dari Indonesia atau luar Indonesia, baik melalui ataupun tanpa melelui bentuk usaha tetap di luar negeri dan juga warisan yang belum terbagi.

a. Orang pribadi

Orang pribadi sebagai subjek pajak yang berada di Indonesia lebih dari 183 hari dalam jangka waktu 12 bulan atau orang pribadi yang dalam 1 tahun pajak berada di Indonesia dan mempunyai niat untuk bertempat tinggal di Indonesia.

b. Badan

Badan adalah sekumpulan orang batau modal yang merupakan kesatuan baik yang melakukan usaha maupun yang tidak melakukan usaha.

c. Warisan yang belum terbagi

Warisan yang belum terbagi sebagai satu kesatuan merupakan Subjek Pajak pengganti. Adapun pihak yang digantikan adalah mereka yang berhak, yaitu ahli waris. Penunjukan warisan yang belum terbagi sebagai Subjk Pajak pengganti bukannya tanpa alasan. Hal ini dimaksudkan agar pengenan pajak atas penghasilan yang berasal dari warisan tersebut tetap dapat dilaksanakan.

2. Subjek Pajak Luar Negeri

Adalah orang pribadi atau badan yang bertempat tinggal atau bertempat kedudukan di luar Indonesia yang dapat menerima atau memperoleh penghasilan dari Indonesia, baik melalui ataupun tanpa melalui bentuk usaha tetap.

a. Orang pribadi

Orang pribadi sebagai Subjek

Pajak luar negeri dapat dibedakan menjadi seperti berikut: Orang pribadi yang tidak bertempat tinggal atau yang berada tidak lebih 183 hari dalam 12 bulan atau tidak berniat tinggal di Indonesia yang menjalankan usaha atau melakukan kegiatan usaha di Indonesia baik atau tanpa BUT, Orang pribadi yng bertempat tinggal atau bertempat kedudukan di luar Indonesia yang dapat menerima atau memperoleh penghasilan dari Indonesia baik melalui ataupun tanpa melalui Bentuk Usaha Tetap merupakan Subjek Pajak luar negeri.

b. Badan

Badan sebagai Subjek Pajak Luar Negeri adalah badan yang bertempat kedudukan di luar Indonesia yang dapat menerima atau memperoleh penghasilan dari Indonesia, baik melalui ataupun tanpa melalui Bentuk Usaha Tetap. Kewajiban pajak subjektif badan sebagai Subjek Pajak luar negeri dimulai pada saat badan mempunyai hubungan ekonomis dengan Indonesia, yaitu menerima atau memperoleh penghasilan dari sumber-sumber di Indonesia. Adapun kewajiban tersebut akan berakhir pada saat badan tersebut tidak lagi mempunyai hubungan ekonomis dengan Indonesia.

c. Bentuk Usaha Tetap

Adalah suatu tempat usaha dimana seluruh atau sebagian usaha dari suatu perusahaan dijalankan oleh Subjek Pajak luar negeri. BUT adalah suatu sarana bagi nonresident taxpayer untuk melakukan bisnis di negara lain, yang berupa agen, perwakilan dagang, cabang atau anak 
perusahaan. BUT dapat berupa orang pribadi atau badan usaha. Penghasilan sebagai Objek Pajak dapat diperoleh dari Indonesia maupun dari luar Indonesia. Berdasarkan negara asal yang menjadi sumber penghasilan tersebut maka Objek Pajak dalam kutipan Djoko Muljono dalam bukunya Pengantar PPh dan PPh 21 (2007:19) dapat dibedakan menjadi seperti berikut ini :

1. Objek Pajak dalam negeri

Adalah penghasilan yang diperoleh Subjek Pajak dalam negeri termasuk BUT maupun Subjek Pajak luar negeri yang berasal dari Indonesia. Penghasilan yang diperoleh dari dalam negeri bias didapat dari berbagai kegiatan, seperti usaha, pekerjaan bebas, karyawan, pemanfaatan modal, dan berbagai cara lainnya yang menimbulkan adanya penghasilan yang didapat di Indonesia. Sebelumnya telah disampaikan pula bahwa penghasilan yang diperoleh BUT yang berasal dari Indonesia bisa dijadikan Objek Pajak dalam negeri.

2. Objek Pajak luar negeri

Adalah penghasilan yang diperoleh Subjek Pajak dalam negeri termasuk BUT yang berasal dari luar negeri yang sudah atau belum dipotong pajak di tempat penghasilan tersebut didapat, tetap merupakan Objek Pajak penghasilan di Indonesia, sedangkan bagi Objek Pajak luar negeri dapat diperhitungkan sebagai kredit pajak di Indonesia sesuai dengan ketentuan Pasal 24 Undangundang $\mathrm{PPh}$.

Pengertian SPT yang dikutip dari Djoko Muljono dalam bukunya Ketentuan Umum Perpajakan (2008:15), SPT adalah surat yang oleh Wajib Pajak digunakan untuk melaporkan perhitungan dan/atau pembayaran pajak, objek pajak dan/ atau bukan objek pajak dan/ atau harta dan kewajiban, sesuai dengan ketentuan peraturan perundang-undangan perpajakan ( Pasal 1 angka 11 UU KUP Dalam melaporkan pembayaran pajak Wajib Pajak harus menggunakan SPT. Ada 2 fungsi SPT yang dikutip dari Djoko Muljono dalam bukunya Ketentuan Umum Perpajakan (2008:15), yaitu :

1. Fungsi Pelaporan

a. Bagi Wajib Pajak Penghasilan, Penghitungan jumlah Wajib Pajak Penghasilan yang sebenarnya terutang.

1. Pembayaran atau pelunasan pajak yang telah dilaksanakan sendiri dan atau melalui pemotongan atau pemungutan pihak lain dalam Tahun Pajak atau bagian Tahun Pajak.

2. Penghitungan penghasilan yang merupakan objek pajak dan atau bukan objek pajak.

3. Harta dan kewajiban.

b. Bagi Pengusaha Kena Pajak.

1. Penghitungan jumlah PPN dan PPnBM yang sebenarnya terutang.

2. Pengkreditan Pajak Masukan terhadap Pajak Keluaran.

3. Pembayaran atau pelunasan pajak yang telah dilaksanakan sendiri oleh PKPdan/ atau melalui pihak lain dalam satu masa pajak.

2. Fungsi Pertanggung jawaban

Fungsi pertanggung jawaban pada Surat Pemberitahuan dapat dibeda kan menurut yang mempertan gung jawabkannya, menjadi seperti berikut ini :

a. Bagi Wajib Pajak

Fungsi pertanggungjawaban SPT atas pembayaran dari kegiatan pemotongan atau pemungutan $\mathrm{PPh}$ dilakukannya terhadap $\mathrm{PPh}$ orang pribadi atau badan lain dalam atu masa pajak. 
b. Bagi Pengusaha Kena Pajak

Bagi PKP sebagai pemotong atau pemungut pajak, fungsi SPT adalah sebagai sarana untuk mempertanggungjawabkan pajak yang dipotong atau dipungut atau disetorkannya.

Pelaporan SPT yang dikutip dari Djoko Muljono dalam bukunya Ketentuan Umum Perpajakan (2008:16) dapat dilakukan Wajib Pajak dengan cara seperti berikut :

1. Pelaporan SPT secara langsung

Pelaporan SPT secara langsung dapat dilakukan oleh Wajib Pajak dengan mengirimkan SPT dalam bentuk fisik langsung ke KPP atau KP2KP termasuk yang dikirimkan melalui media pengiriman seperti kantor pos atau lainnya.

Tata cara pelaporan SPT secara langsung dilakukan Wajib Pajak atau KKP dengan cara tahapan seperti berikut :

\section{a. Pengambilan formulir SPT}

Pada dasarnya formulir SPT harus diambil sendiri oleh Wajib Pajak, baik langsung ke KKP atau KP2KP atau dapat di-download pada situs Direktorat Jenderal Pajak. Namun demikian dengan alasan pelayanan, formulir SPT tersebut dapat dikirimkan oleh Direktorat Jenderal Pajak kepada Wajib Pajak, terutama atas SPT Tahunan.

b. Pengisian SPT

Pengisian SPT sesuai dengan petunjuk yang diberikan berdasarkan ketentuan peraturan perundang-undangan perpajakan dilakukan dengan :
1. Benar
2. Jelas
3. Lengkap

c. Penandatangan SPT

SPT telah dianggap lengkap apabila telah ditandatangani oleh yang berhak menandatangani
SPT. Untuk Wajib Pajak orang pribadi ditandatangani oleh Wajib Pajak yang bersangkutan, sedangkan untuk Wajib Pajak badan ditandatangani oleh pengurus atau direksi. Dan dalam hal SPT diisi dan ditandatangani oleh orang lain bukan Wajib Pajak, harus dilampiri surat kuasa khusus.

d. Penyampaian SPT.

Penyampaian fisik SPT dapat dilakukan Wajib Pajak

Pelaporan SPT dapat dilakukan secara elektronik atau melalui system e-filling. Seorang Wajib Pajak dapat menyampaikan SPTsecara e-filling melalui perusahaan penyedia jasa aplikasi yang ditunjuk oleh Dirjen Pajak. Wajib Pajak yang telah menyampaikan SPT secara e-felling, Wajib menyampaikan induk SPT yang memuat tanda tangan basah dan Surat Setoran Pajak (bila ada) serta bukti penerimaan secara elektronik ke KPP tempat Wajib Pajak terdaftar melalui kantor pos secara tercatat atau disampaikan langsung, paling lambat 14 hari sejak tanggal penyampaian SPT secara elektronik. Penyampaian SPT secara elektronik dapat dilakukan selama 24 jam sehari dan 7 hari seminggu. SPT yang disampaikan secara elektronik pada akhir batas waktu penyampaian SPT yang jatuh pada hari libur, dianggap disampaikan tepat waktu.

SPT dilihat dari kapan harus dilaporkan ke Dirjen Pajak yang dikutip dari Djoko Muljono (2008:23) dapat dibedakan menjadi :

1. SPT Masa.

Adalah jangka waktu yang menjadi dasar bagi Wajib Pajak untuk menghitung, menyetor dan melaporkan pajak yang terutang dalam suatu jangka waktu tertentu sebagaiman ditentukan dalam 
undang-undang ini ( pasal 1 huruf 7 UU KUP)

Batas waktu penyampaian SPT Masa adalah paling lambat 20 hari setelah masa berakhirnya Masa Pajak. Lamanya masa pajak adalah 1 bulan kalender atau paling lama 3 bulan kalender.

Jenis pajak yang harus dilaporkan SPT masa antara lain :

a. PPh Pasal 21/26

b. PPh Pasal 22

c. PPh Pasal 23/26

d. PPh Pasal 25

e. PPh Pasal 4 (2)

f. PPh Pasal 15

g. PPN DAN PPnBM

SPT masa Wajib Pajak kritera tertentu seperti Wajib Pajak Usaha Kecil dapat dilakukan dengan mempergunakan 1 SPT untuk beberapa masa pajak, dengan syarat pembayaran pajak dilakukan untuk : SPT masa PPh Pasal 25 dibayar semuanya pada saat SPT dilakukan, sampai dengan masa pajak yang digabung pada SPT, SPT lainnya, pembayaran pajaknya tidak melebihi batas waktu setiap masanya.

2. SPT Tahunan.

Adalah jangka waktu satu tahun kalender kecuali bila Wajib Pajak menggunakan tahun buku yang tidak sama dengan tahun kalender (pasal 1 huruf 8 UU KUP). Bagian tahun pajak adalah bagian dari jangka waktu 1 tahun pajak (pasal 1 huruf 9 UU KUP)

Batas waktu penyampaian SPT Tahunan WP pribadi paling lama 3 bulan setelah akhir tahun pajak. Bagi yang tahun pajaknya menggunakan tahun kalender, maka 3 bulan tersebut sama dengan akhir bulan Maret tahun kalender berikutnya.

Batas waktu WP badan paling lama 4 bulan setelah akhir tahun pajak. Bagi yang tahun pajaknya menggunakan tahun kalender, maka 4 bulan tersebut sama dengan akhir bulan April tahun kalender berikutnya.

Jenis pajak yang harus dilaporkan melalui SPT Tahunan antara lain adalah:

a. PPh Pasal 21.

b. PPh Badan.

c. PPh Badan US \$.

d. PPh Orang Pribadi.

e. PPh Orang Pribadi Karyawan.

SPT yang telah diterima oleh Direktorat Jenderal Pajak akan dikelompokkan oleh Direktorat Jenderal Pajak yang dikutip dari Djoko Muljono dalam bukunya Ketentuan Umum Perpajakan (2008:21) dapat dibedakan sebagai berikut :

1. Menurut jenis SPT
a. SPT tahunan.
b. SPT masa.

2. Menurut Wajib Pajak.
a. SPT Wajib Pajak Bendaharawan.
b. SPT Wajib Pajak Orang Pribadi.
c. SPT Wajib Pajak Badan dan BUT.

3. Menurut Orang pribadi.
a. SPT PPh Tahunan Orang Pribadi.
b. SPT PPh Tahunan Orang Pribadi Karyawan.
c. SPT PPh Tahunan Badan.
d. SPT PPh 21 Tahunan.

4. Menurut kriteria SPT.
a. SPT Lebih Bayar.
b. SPT Kurang Bayar.
c. SPT Nihil.
d. SPT Rugi Tidak Lebih Bayar.
e. SPT Rugi Lebih Bayar.

Berikut ini adalah Wajib Pajak Perseorangan yang wajib mengisi SPT Tahunan yang dikutip dari Sunarto SE., MM dalam bukunya Perpajakan 1 (2004:55) sebagai berikut:

1. Wajib Pajak Perseorangan yang memperoleh atau menerima penghasilan dari kegiatan usaha dan/atau pekerjaan bebas, baik yang menyelenggarakan pembukuan penghasilan maupun menyelenggarakan pencatatan 
2. Karyawan/karyawati memperoleh atau penghasilan lain di luar penghasilan sehubungan dengan pekerjaan dan/atau yang memeperoleh penghasilan sehubungan dengan pekerjaan lebih dari satu pemberi kerja.

3. Pihak-pihak yang diberi kuasa warisan yang belum dibagi.

4. Wajib Pajak Perseorangan yang memperoleh penghasilan dari modal dan lain-lainnya dengan menyelenggara kan pencatatan.

5. Warga Negara Indonesia yang bekerja di Kantor Kedutaan Asing, Konsultan Asing dan Perwakilan Organisasi Internasional yang ditentukan oleh Menteri Keuangan.

6. Warga Negara Asing yang tinggal di Indonesia lebih dari 183 hari dalam jangka waktu 12 bulan atau orang yang dalam 1 tahun pajak berada di Indonesia dan mempunyai niat tinggal di Indonesia.

Sedangkan untuk Wajib Pajak Badan yang wajib mengisi SPT adalah semua Wajib Pajak Badan dengan nama dan dalam bentuk apapun. Pengisian penyampaian SPT yang dikutip dari http:/perpajakan.web.id/pph/seputarsurat-pemberitahuan-spt.com (diakses tanggal 12 April 2009) terbagi atas:

1. Setiap Wajib Pajak wajib mengisi SPT dalam bahasa Indonesia dengan menggunakan huruf latin, angka arab, satuan mata uang Rupiah, dan menandatangani serta menyampaikannya ke kantor Direktorat Jenderal Pajak tempat Wajib Pajak terdaftar atau dikukuhkan.

2. Wajib Pajak yang telah mendapat izin Menteri Keuangan untuk menyelenggarakan pembukuan dengan menngunakan bahasa asing dan mata uang Rupiah, wajib menyampaikan SPT dalam bahasa
Indonesia dan mata uang selain Rupiah yang diizinkan.

PPH Pasal 25 merupakan angsuran pajak yang dibayar WP setiap bulannya. Pajak Penghasilan dikenakan terhadap WP dalam satu periode tertentu yang dinamakan tahun pajak. Berdasarkan hal ini, maka perhitungan dan perhitungan $\mathrm{PPh}$ dilakukan setahun sekali yang dituangkan dalam SPT Tahunan. Karena perhitungan $\mathrm{PPh}$ dilakukan setahun sekali, maka penghitungan ini harus dilakukan setelah satu tahun tersebut berakhir agar semua data penghasilan dalam satu tahun sudah diketahui. Untuk perusahaan, tentu saja data penghasilan ini harus menunggu laporan keuangan selesai. Wajib Pajak yang wajib menyetor PPh Pasal 25 namun tidak menyetor $\mathrm{PPh}$ Pasal 25 atau kurang menyetor PPh Pasal 25, akan diterbitkan surt ketetapan pajak untuk menagih PPh Pasal 25 yang tidak atu kurang disetor ditambah dengan sanksi administrasi sesuai dengan ketentuan undang-undang perpajakan.

Dasar hukum PPh Pasal 25 adalah :

1. Pasal 25 Undang-undang Nomor 7 tahun 1983 sttdd Undang-undang Nomor 36 Tahun 2008 tentang Pajak Penghasilan.

2. Peraturan Menteri Keuangan No.255/KMK.04/2000 tentang Perhitungan Besarnya Angsuran Pajak Penghasilan Dalam Tahun Berjalan yang Harus Dibayar Sendiri oleh Wajib Pajak Baru, Bank, Sewa Guna Usaha dengan Hak Opsi, BUMN, BUMD, Wajib Pajak Masuk Bursa dan Wajib Pajak Lainnya yang Berdasarkan Ketentuan Diharuskan Membuat Laporan Keuangan Berkala Ternasuk Wajib Pajak Orang Pribadi Pengusaha Tertentu.

3. Keputusan Direktur Jenderal Pajak No. KEP-537/PJ./2000 tentang Perhitungan Besarnya Angsuran 
Pajak dalam Tahun Berjalan Dalam Hal-hal Tertentu.

a. Wajib Pajak memperoleh penghasilan tidak teratur.

b. Surat Pemberitahuan Tahunan Pajak Penghasilan tahun pajak yang lalu disampaikan setelah lewat batas waktu yang ditentukan.

c. Wajib Pajak diberikan perpanjangan jangka waktu penyampaian Surat Pemberitahuan Wajib Pajak berhak atas kompensasi kerugian.

4. Keputusan Dirjen Pajak: KEP207/PJ./2001 tentang Kewajiban Menyampaikan Surat Pemberitahuan Masa PPh Pasal 25 untuk Wajib Pajak Orang Pribadi.

Besarnya angsuran PPh Pasal 25 harus dihitung sesuai dengan ketentuan. Pada umumnya, cara menghitung $\mathrm{PPh}$ Pasal 25 didasarkan kepada data SPT Tahunan tahun sebelumnya. Artinya, kita mengasumsikan bahwa penghasilan tahun ini sama dengan penghasilan tahun sebelumnya. Tentu saja nanti akan ada perbedaan dengan kondisi sebenarnya ketika tahun pajak sekarang sudah berakhir. Selisih tersebutlah yang kita bayar sebagai kekurangan pajak akhir tahun. Kekurangan bayar akhir tahun ini biasa dinamakan PPh Pasal 29. Apabila selisihnya menunjukkan lebih bayar, maka kondisi ini dinamakan restitusi atau Wajib Pajak meminta kelebihan pembayaran pajak yang telah dilakukan. Pada umumnya angsuran pajak ini adalah sebesar Pajak Penghasilan terutang menurut SPT Tahunan Pajak Penghasilan tahun lalu dikuranggi dengan kredit pajak Pajak Penghasilan Pasal 21, 22, 23 dan Pasal 24, dibagi 12 atau banyaknya bulan dalam bagian tahun pajak.

\section{Hipotesis}

Dari perumusan masalah pada bab sebelumnya, maka penulis mengemuka kan hipotesa sebagai berikut:Diduga perusahaan melakukan perhitungan dan pelaporan PPh Pasal 25 sesuai dengan ketentuan perpajakan.

\section{METODE PENELITIAN}

Sumber data yang penulis gunakan dalam penelitian ini adalah :

a. Data primer adalah data yang diperoleh langsung dari perusahaan sebagai objek penelitian. Data ini diperoleh melalui wawancara dengan pihak peusahaan pada bagian keuangan, karyawan dan pihak yang terkait.

b. Data sekunder adalah data yang diperoleh dari dokumen-dokumen serta laporan keuangan yaitu laporan laba rugi dan neraca, daftar harta dan perhitungan penyusutan, serta daftar penyusutan dan amortisasi fiskal, surat pemberitahuan pajak perusahaan dalam 3 tahun terakhir.

Metode atau teknik pengumpulan data yang penulis gunakan dalam penelitian ini adalah :

1. Field Research ( Penelitian Lapangan )

Merupakan penelitian langsung kepada Pt Selago Makmur Palntation yang digunakan sebagai pendukung data primer. Adapun metode yang penulis lakukan adalah

a. Observasi

Yaitu melakukan pengamatan langsung pada perusahaan yang menjadi objek penelitian untuk mendapatkan data.

b. Wawancara

Mengumpulkan data dengan cara menanyakan langsung kepada pihak yang bersangkutan mengenai topic yang dibahas.

2. Library Research ( Penelitian Kepustakaan ) Yaitu penulis mengumpul kan data dengan membaca dan mempelajari 
literature-literatur, karya ilmiah, penelitian terdahulu, serta bahanbahan yang diperoleh dari kuliah maupun dari perpustakaan atau sumber-sumber lain yang terkait dengan masalah yang akan dibahas.

Dalam penelitian ini penulis menggunakan beberapa analisa yaitu :

1. Analisis kualitatif

Dalam metode ini penulis melakukan suatu analisa deskriptif, yaitu dengan membandingkan antara bahan bacaan dengan kenyataan yang ditemui di lapangan sehingga dapat menghasilkan solusi yang baik dan optimal. Dengan membaca dan mempelajari peraturan perpajakan yang berupa Undang-Undang No

$\mathrm{PPh}$ Pasal $25=$
36 Tahun 2008 atau biasa disebut dengan Undang-Undang PPh.

2. Analisis kuantitatif

Dalam metode ini penulis menggunakan metode kuantitatif yang relevan, yaitu dengan menggunakan perhitungan dan pencatatan $\mathrm{PPh}$ Pasal 25 dengan memakai data laporan laba rugi tahunan PT SELAGO MAKMUR PLANTATION pada tahun 2007 untuk melakukan perhitungan dan pelaporan $\mathrm{PPh}$ Pasal 25 dengan melakukan perhitungan PPh Pasal 25 terlebih dahulu dari tahun 2007.

Rumus yang digunakan dalam perhitungan $\mathrm{PPh}$ Pasal 25 dihitung berdasarkan SPT tahun lalu

\section{HASIL DAN PEMBAHASAN}

Dasar perhitungan untuk menentukan besarnya pajak penghasilan yang terhutang adalah Penghasilan Kena Pajak ( PKP). Besarnya Penghasilan Kena Pajak dapat diketahui dari Laporan Laba Rugi Wajib Pajak yang menyelenggarakan pembukuan. Penghasilan Kena Pajak inilah yang menjadi dasar pengenaan tarif pajak sesuai ketentuan perpajakan yang berlaku. Menurut Undang-Undang Pajak Penghasilan No. 17 tahun 2000 (pasal 17) yang mulai berlaku pada tahun 2001 dengan tarif yang berlaku sebagai berikut:

\begin{tabular}{|l|c|}
\hline $\begin{array}{l}\text { Lapisan Penghasilan } \\
\text { Kena Pajak }\end{array}$ & $\begin{array}{c}\text { Tarif } \\
\text { Pajak }\end{array}$ \\
\hline $\begin{array}{l}\text { Sampai dengan Rp. } \\
50.000 .000\end{array}$ & $10 \%$ \\
\hline
\end{tabular}

\begin{tabular}{|l|c|}
\hline Diatas Rp. 50.000.000 s/d & $15 \%$ \\
Rp.100.000.000 & \\
\hline Diatas Rp. 100.000 .000 & $30 \%$ \\
\hline
\end{tabular}

Yang pada tahun 2009 tarif pajak yang dikenakan sebesar 28\% dan tahun 2010 dikenakan tarif pajak sebesar $25 \%$.

Setelah didapat besarnya Penghasilan Kena Pajak tahun 2006 menurut akuntansi yaitu sebesar Rp. 27.174.328.717 dan menurut fiskal $\mathrm{Rp}$. 28.059.199.613 dan tahun 2007 menurut akuntansi yaitu sebesar Rp. 69.374.498.380 dan menurut fiskal $\mathrm{Rp}$. 69.515.475.455 maka langkah selanjutmya adalah menghitung besarnya pajak yang terhutang.

Perhitungan pajak penghasilan PT SELAGO MAKMUR PLANTATION yang terhutang adalah sebagai berikut: 
a. Tahun 2010

Penghasilan kena pajak perusahaan tahun 2006 yaitu sebesar Rp. 28.059.199.613 dapat dihitung sebagai berikut:
$10 \%$ x Rp. $50.000 .000 \quad=$ Rp. $\quad 5.000 .000$
$15 \%$ x R. $50.000 .000 \quad=$ Rp. $\quad 7.500 .000$
$30 \% \times$ Rp. 27.959.199.613 = Rp.
Jumlah PPH yang Terhutang Rp.
8.400.259.883

Jadi pada tahun 2006, perusahaan harus membayar pajak penghasilan badannya adalah sebesar Rp. 8.400.259.883

b. Tahun 2011

Penghasilan kena pajak perusahaan tahun 2007 yaitu sebesar Rp. 69.716.989.886 dapat dihitung sebagai berikut:
$10 \%$ x Rp. 50.000 .000
$=\mathrm{Rp}$.
5.000 .000
$15 \% \times$ Rp. $50.000 .000=$ Rp.
7.500 .000
$30 \% \times$ Rp. 69.616.989.886 = Rp.
20.885.096.700
Jumlah PPH yang Terhutang Rp.
20.897.596.700

Jadi pada tahun 2007, perusahaan harus membayar pajak penghasilan badannya adalah sebesar Rp. 20.897.596.700

Dari kertas kerja rekonsiliasi fiskal diatas dapat dilakukan perhitungan $\mathrm{PPH}$ Pasal 25 yang biasa dikenal dengan angsuran pajak. Berikut ini perhitungan PPH Pasal 25 yang dibayarkan perusahaan adalah sebagai berikut:

a. Tahun 2010

PPH yang terhutang

Rp. 8.400 .259 .883

Dikurangi :

$\begin{array}{ll}\text { PPH Pasal 22 } & \text { Rp. } 21.234 .480 \\ \text { PPH Pasal 23 } & \text { Rp. 725.624.567 }\end{array}$

Jumlah kredit pajak $\quad$ Rp. 746.859 .047

Selisih

Rp. 7.653.400.836

$\mathrm{PPh}$ Pasal 25 yang dibayarkan perusahaan adalah sebesar Rp. 637.783 .403 ( Rp.

7.653.400.836: 12)

b. Tahun 2011

PPH yang terhutang

Dikurangi :

PPH Pasal $22 \quad$ Rp. 116.854 .191

PPH Pasal $23 \quad$ Rp. 2.156.042.864

Jumlah kredit pajak

Selisih

Rp. 20.897.569.700

Rp. $\quad 2.272 .897 .055$

Rp. 18.624 .699 .643

PPh Pasal 25 yang dibayarkan perusahaan adalah sebesar Rp. 1.552.058.304 ( Rp. 18.624.699.643: 12)

Pelaporan PPH Pasal 25 Pada PT

Selago Makmur Plantation PPH Pasal

25 disetor ke bank persepsi atau kantor

pos dan giro dengan menggunakan

Surat Setoran Pajak ( SSP) paling lambat tanggal 15 bulan berikutnya setelah masa ajak tersebut berakhir. SSP lembar ke 3 atas PPH Pasal 25 wajib dilaporkan ke Kantor Pelayan Pajak tempat Wajib Pajak terdaftar 
paling lambat tanggal 20 bulan berikutnya. Orang Pribadi yang tidak melakukan usaha atau pekerjaan bebas dan besarnya PPH Pasal 25 menurut SPT Tahunan adalah nihil, tidak mempunyai kewajiban menyampaikan SPT Masa PPH Pasal 25.

SPT disampaikan pada Kantor Pelayanan Pajak, dalam penyampaian tersebut tidak dilakukan penelitian. Yang mana penelitian terhadap SPT dilakukan paling lama 2 bulan setelah SPT diterima. Setelah pembayaran dilakukan, SPT Tahunan langsung dilaporkan ke Kantor Pajak dan beberapa hari setelah itu menerima surat tanda terima SPT sebagai bukti bahwa SPT yang diterima sudah lengkap. SPT dapat dilihat pada lampiran formulir 11771 SPT Tahunan. Pt Selago Makmur membayar SPT Tahunan di Bank Mandiri dengan NPWP.

\section{SIMPULAN}

Dari hasil pembahasan yang telah diuraikan pada bab sebelumnya mengenai laba akuntansi dengan penghasilan/ laba kena pajak pada PT SELAGO MAKMUR PLANTATION, maka berikut ini penulis mencoba untuk memberikan kesimpulan sebagai berikut:

1. Pada perusahaan yang penulis teliti, terdapat koreksi fiskal positif dan koreksi fiskal negatif pada tahun 2010 dan tahun 2011 pada laporan keuangan komersial, yaitu:

2. Pada tahun 2010 terdapat koreksi positif pada beban imbalan pasca kerja sebesar Rp. 125.296.900,00 dan beban SPT Tahunan Pasal 21 sebesar Rp. 12.950.280,00 dan koreksi fiskal negatif pada pendapatan jasa giro sebesar Rp. 32.147.077,01.

3. Pada tahun 2011 terdapat koreksi fiskal positif pada beban imbalan pasca kerja sebesar Rp.
236.673.570,30, beban SKP PPh sebesar Rp. 171.507.451,00, PPh Pasal 29 sebesar Rp. 20.006.979,00 dan koreksi fiskal negarif pada pendapatan jasa giro sebesar Rp. 90.696.494,38.

4. Perbedaan pengakuan pendapatan dan biaya antara Standar Akuntansi Keuangan dengan Undang-Undang No. 17 tahun 2000 akan menyebabkan jumlah laba akuntansi berbeda dengan laba fiskal/ laba kena pajak. Laba menurut akuntansi komersial pada PT SELAGO MAKMUR PLANTATION pada tahun 2006 adalah sebesar Rp. 19.045.289.387,12 dan pada tahun 2007 sebesar Rp. 48.547.903.580,61 dan setelah dilakukan koreksi, besarnya laba fiskal pada tahun 2006 sebesar Rp. 19.943.110.563 dan Rp. 48.840.381.127,03.

Perbedaan jumlah ini akan mempunyai dampak terhadap pajak penghasilan terutang perusahaan. Jika dihitung dari laba akuntansi komersial, besarnya pajak penghasilan perusahaan tahun 2006 sebesar Rp. 8.400.259.883 dan Rp. 20.897.596.700 tahun 2013.

5. Perhitungan PPH Pasal 25 yang dibayarkan perusahaan pada tahun 2010 adalah sebesar Rp. Rp. 637.783.403 dan pada tahun 2011 PPH Pasal 25 yang dibayarkan perusahaan adalah sebesar Rp. Rp. 1.552.058.304.

6. Pada prinsipnya tidak ada pembukuan atau akuntansi yang khusus diselenggarakan untuk memenuhi kewajiban perpajakan. Perangkat akuntansi, baik untuk manajemen mnaupun perpajakan adalah sama. Yamg berbeda adalah cara penyusunan laporan keuangan yang akan disampaikan kepdada aparat perpajakan disusun berdasarkan undang-undang perpajakan yang berlaku. Oleh 
karen itu laporan keuangan komersial harus direkonsiliasi dengan melakukan koreksi fiskal dengan mengikuti undang-undang perpajakan yang berlaku.

\section{DAFTAR PUSTAKA}

Adiani, Prof. Dr. P.J.A. 1991. Pajak Penghasilan. Jakarta: Penerbit Fakultas Ekonomi Universitas Indonesia

B. Ilyas, Irawan, Rudy Suhartono. 2007. Pajak Penghasilan. Jakarta: Penerbit Fakultas Ekonomi Universitas Indonesia

Muljono, Djoko. 2007. Ketentuan Umum Perpajakan. Yogyakarta: Penerbit Andi

Muljono, Djoko. 2007. Pemotongan Pemungutan PPH\& PPH Pasal 25/29. Yogyakarta: Penerbit Andi

Muljono, Djoko. 2007. Pengantar PPH dan PPH 21. Yogyakarta: Penerbit Andi

Mardiasmo, Prof. Dr. MBA. 2006. Perpajakan. Yogyakarta: Penerbi Andi

Nigthtingale. $2005 . \quad$ Pajak Penghasilan. Jakarta: Penerbit Fakultas Ekonomi Universitas Indonesia

Ridwan, Drs. M.B.A. Metode\& Teknik Menyusun Proposal Penelitian.

Bandung: Penerbit Alfabeta

Sunarto. 2004. Perpajakan 1 . Yogyakarta: Penerbit AMUS Yogyakarta\& Mahenoko Total Design Yogyakarta

Suandy, Erly. 2006. Perencanaan Pajak. Jakarta: Salemba Empat Sunarto, SE, MM. 2003. Perpajakan 2. Yogyakarta: Penerbit AMUS Yogyakarta dan CV. Ngeksigondo Multisarana Utama

Soemitro, Prof. Dr. Rochmat 1993.

Pajak Penghasilan. Jakarta:
Penerbit Fakultas Ekonomi Universitas Indonesia

S. I. Djajaningrat. 1995. Pajak Penghasilan. Jakarta: Penerbit Fakultas Ekonomi Universitas Indonesia

S. R., Soemarso. 2007. Perpajakan. Jakarta: Salemba Empat http:/perpajakan.web.id/pph/seputar -surat-pemberitahuan-spt.com( Accesed 12 April 2009) 